\title{
Evidence of genetic tolerance to low availability of phosphorus in the soil among genotypes of Coffea canephora
}

\author{
L.D. Martins ${ }^{1}$, W.N. Rodrigues ${ }^{1}$, L.S. Machado ${ }^{1}$, S.V.B. Brinate ${ }^{1}$, T.V. Colodetti ${ }^{1}$, \\ J.F.T. Amaral ${ }^{2}$ and M.A. Tomaz ${ }^{1}$ \\ ${ }^{1}$ Programa de Pós-Graduação em Produção Vegetal, \\ Centro de Ciências Agrárias da Universidade Federal do Espírito Santo, Alegre, \\ ES, Brasil \\ ${ }^{2}$ Departamento de Engenharia Rural, Centro de Ciências Agrárias, \\ Universidade Federal do Espírito Santo, Alegre, ES, Brasil \\ Corresponding author: L.D. Martins \\ E-mail: deleon_lima@hotmail.com
}

Genet. Mol. Res. 14 (3): 10576-10587 (2015)

Received March 4, 2015

Accepted June 9, 2015

Published September 8, 2015

DOI http://dx.doi.org/10.4238/2015.September.8.19

\begin{abstract}
The expansion of agriculture to new areas in order to increase the competitiveness of coffee producing countries has resulted in cultivation expanding into regions with lower natural fertility. This scenario has created the need to differentiate genotypes of Conilon coffee based on their tolerance to low levels of nutrients in the soil, especially phosphorus, which imposes high limitations on crop yield in tropical regions. In this context, the objective of this study was to identify differential tolerance among genotypes of Conilon coffee cultivated in environments with different levels of phosphorus availability in the soil. The experiment was conducted in
\end{abstract}


a controlled environment, following a completely randomized design, with three replications in a factorial scheme $13 \times 3$, the factors were as follows: 13 genotypes of Conilon coffee from groups of different ripening cycles and three environments with different levels of phosphorus availability in the soil (fertilization without phosphorus supply, and phosphorus supply at 50 and $100 \%$ of recommendations). Discrimination of tolerance was based on 14 variables, including vegetative growth, accumulation of dry matter, nutrient content, and nutritional efficiencies. Estimates of genetic parameters indicated high genotypic variability for genotypes cultivated in environments with low phosphorus availability in the soil. It was possible to classify genotypes $22,23,24,67,76,77$, and 83 as tolerant of a low availability of phosphorus in the soil during early development. There was no clear relationship between ripening cycles and the tolerance of the genotypes to low phosphorus availability in the soil.

Key words: Conilon coffee; Mineral nutrition; Fertilization

\section{INTRODUCTION}

The expansion of agriculture to new areas in order to increase the competitiveness of coffee producing countries has resulted in cultivation expanding into regions with lower natural fertility, especially for phosphorus $(P)$, which imposes high limitations on biomass accumulation and crop yield in tropical regions (Novais et al., 2007). This scenario has led to fertilization managements using greater amounts of fertilizers containing $P$, thereby increasing production costs and increasing the need for knowledge to mitigate the situation.

Scientific advances are very relevant in relation to the production of Conilon coffee (Coffea canephora Pierre ex Froenher), especially studies focusing on genetic improvement, growth, development, nutrition, and nutritional efficiency (Fonseca et al., 2004; DaMatta et al., 2007; Ferrão et al., 2008; Bragança et al., 2010; Martins et al., 2013a,b,c; Prezotti and Bragança, 2013; Barbosa et al., 2014). However, it is still necessary to elucidate many processes involved in the expression of nutritional tolerance.

Conilon coffee exhibits high genetic variability, which allows identification of individuals with different characteristics within the species (Ferrão et al., 2008). This fact is related, among other traits, to the allogamous reproduction of the species, which, during evolution, provided numerous random crossings that expanded its genetic basis (Lashermes et al., 1996). This great variability is extremely important for breeding programs; however, for other areas of research that aim to improve the management of plantations with Conilon coffee it promotes a common challenge, since it is not possible to systematize a unique management that is efficient for all recommended cultivars. This difficulty becomes evident for the mineral nutrition of Conilon coffee. The cultivated genotypes of this species present different characteristics of dry matter accumulation (Prezotti and Bragança, 2013), nutritional efficiency, and responsiveness (Martins et al., 2013a,b) when fertilized with similar levels of nutrient supply. Genetic variation is one of the main factors that promotes differences in mineral nutrition of genotypes of the same species (Fageria, 1998), and it is extremely important to investigate genotypes with the potential to adapt to different cultivation 
conditions (Machado et al., 2004; Tomaz et al., 2011).

In this context, the main solution to increase productivity and reduce the costs due to the use of fertilizers is to identify genotypes that are more suitable for each cultivation system. Selection of tolerant genotypes, adapted to low availability of nutrients in the soil, becomes necessary for regions with soils with low natural fertility, especially $P$, which imposes high limitations on crop yields in tropical regions (Silva et al., 2010; Amaral et al., 2012). By definition, a plant is considered tolerant to a deficit of $P$ in the soil when it is able to develop even in conditions of insufficient nutrient availability with maximum productivity, being able to produce, for example, high amounts of dry matter per unit of time and area (Fox, 1978).

The exploitation of tolerant genotypes in plant breeding programs is critical to enable the adaptation of cultivars to soil conditions with limitations regarding their fertility (Lana et al., 2006; Rotili et al., 2010). However, there are still few methodologies capable of differentiating genotypes with regard to tolerance to low level of nutrients in the soil. One of the methods is based on the use of Anderson's discriminant functions, classifying genotypes with unknown behavior in known groups (tolerant and intolerant), based on their relevance to the diversity of a set group of selected plant traits (Colodetti et al., 2014). The objective of this study was to identify evidence of differential tolerance among genotypes of Conilon coffee cultivated in environments with different levels of $P$ availability in the soil.

\section{MATERIAL AND METHODS}

\section{Description of the study area and plant material}

The experiment was conducted in a greenhouse, located at the experimental site of Centro de Ciências Agrárias of Universidade Federal do Espírito Santo (CCA/UFES), in the municipality of Alegre, southern Espírito Santo State, at latitude $20^{\circ} 45^{\prime} \mathrm{S}$, longitude $41^{\circ} 33^{\prime} \mathrm{W}$, and $277.41 \mathrm{~m}$ in altitude.

The genotypes of $C$. canephora studied in this experiment were grouped based on their ripening cycle: genotypes $02,23,32,48$, and 67 have an early ripening cycle; genotypes $22,31,73,77$, and 83 have an intermediate ripening cycle; and genotypes 24, 76, and 153 have a late ripening cycle. These genotypes were developed by the breeding program established by Incaper (Instituto Capixaba de Pesquisa, Assistência Técnica e Extensão Rural), and they feature desirable agronomic traits and adaptation to cultivation in the State of Espírito Santo, Brazil. The seedlings used in the study were multiplied asexually through cuttings and underwent 120 days of development, presenting two pairs of green leaves and good phytosanitary and nutritional aspects.

The soil used in the experiment was collected from a depth of 10 to $40 \mathrm{~cm}$, with the first 10 $\mathrm{cm}$ of soil being discarded in order to reduce the effects of organic matter present in the superficial layer. A sample of this soil was sent to the laboratory for chemical and physical analyses (Table 1), and the soil was characterized as a dystrophic oxisol of clayey texture (Embrapa, 1997). The entire volume of soil was dried in the shade, homogenized with a 4.0- $\mathrm{mm}$ mesh sieve, and separated into samples of $10-\mathrm{dm}^{3}$ samples by weighing on a precision scale. The samples were placed in sealed pots with a 14-L capacity. 
Table 1. Physical and chemical characteristics of the soil used as the substrate to grow genotypes of Coffea canephora.

\begin{tabular}{|c|c|}
\hline Attribute & Values \\
\hline Coarse sand $(\mathrm{g} / \mathrm{kg})^{1}$ & 395.30 \\
\hline Fine sand $(\mathrm{g} / \mathrm{kg})^{1}$ & 157.70 \\
\hline Silt $(\mathrm{g} / \mathrm{kg})^{1}$ & 43.60 \\
\hline Clay $(g / k g)^{1}$ & 403.40 \\
\hline Soil density $\left(\mathrm{kg} / \mathrm{dm}^{3}\right)^{2}$ & 1.20 \\
\hline $\mathrm{pH}^{3}$ & 5.40 \\
\hline $\mathrm{P}\left(\mathrm{mg} / \mathrm{dm}^{3}\right)^{4}$ & 2.00 \\
\hline $\mathrm{K}\left(\mathrm{mg} / \mathrm{dm}^{3}\right)^{5}$ & 93.0 \\
\hline $\mathrm{Ca}\left(\mathrm{cmolc} / \mathrm{dm}^{3}\right)^{6}$ & 1.70 \\
\hline $\mathrm{Mg}\left(\mathrm{cmolc} / \mathrm{dm}^{3}\right)^{6}$ & 1.10 \\
\hline Al $\left(\mathrm{cmolc} / \mathrm{dm}^{3}\right)^{6}$ & 0.00 \\
\hline $\mathrm{H}+\mathrm{Al}\left(\mathrm{cmolc} / \mathrm{dm}^{3}\right)^{6}$ & 2.10 \\
\hline Sum of bases $\left(\mathrm{cmolc} / \mathrm{dm}^{3}\right)$ & 3.37 \\
\hline CEC potential $\left(\mathrm{cmolc} / \mathrm{dm}^{3}\right)$ & 5.45 \\
\hline CEC effective $\left(\mathrm{cmolc} / \mathrm{dm}^{3}\right)$ & 3.37 \\
\hline Saturation per bases (\%) & 61.80 \\
\hline
\end{tabular}

${ }^{1}$ Pipette method (slow mixing); ${ }^{2}$ graduated cylinder method; ${ }^{3} \mathrm{pH}$ in water (relation 1:2.5); ${ }^{4}$ extracted by Mehlich 1 and determined by colorimetry; ${ }^{5}$ extracted by Mehlich 1 and determined by flame photometry; ${ }^{6}$ extracted with $1 \mathrm{M}$ potassium chloride and determined by titration (EMBRAPA, 1997).

\section{Experimental design and conduct of the study}

The experiment was conducted in a controlled environment, following a completely randomized design, with three replications in a factorial scheme of $13 \times 3$. The factors were 13 genotypes of Conilon coffee divided into three groups based on differences in the ripening cycle, and three environments with different levels of $\mathrm{P}$ availability in the soil: fertilization without $\mathrm{P}$ supply, and $P$ supply at 50 and $100 \%$ of the recommended level (see Martins et al., 2013b).

The application of $\mathrm{P}$ in soil was based on recommendations for Conilon coffee (Lani et al., 2007), using the levels of 0,50 , and $100 \%$ of the recommended level $(0.000,0.312$, and $0.625 \mathrm{~g} /$ $\mathrm{kg}$ phosphorus pentoxide $\left(\mathrm{P}_{2} \mathrm{O}_{5}\right)$, respectively) in order to discriminate characteristics related to the tolerance of low availability of $\mathrm{P}$ in the soil, as indicated by previous results (Martins et al, 2013b). The level of $\mathrm{P}$ available in the soil was managed by applying monopotassium phosphate $\left(\mathrm{KH}_{2} \mathrm{PO}_{4}\right)$ diluted in distilled water and homogenizing the solution in the soil sample of each pot. The amount of potassium provided was balanced to the level of $0.45 \mathrm{~g} / \mathrm{kg}$ of potassium oxide $\left(\mathrm{K}_{2} \mathrm{O}\right)$ in all the pots; whereas for treatments with a reduced supply of $\mathrm{P}$, fertilization with potassium was made with the addition of potassium chloride $(\mathrm{KCl})$, diluted in distilled water, and homogenized in the volume of soil in the pot before planting.

Nitrogen fertilization was performed using urea $\left(\mathrm{NH}_{2} \mathrm{CONH}_{2}\right)$ diluted in distilled water and applied over the soil surface, circulating $10 \mathrm{~cm}$ away from the plants. Total nitrogen fertilization $(17.3 \mathrm{~g} / \mathrm{kg})$ was divided into five applications: the first after planting and the other four at $30,60,90$, and 120 days after planting (Lani et al., 2007).

Irrigation was performed daily, returning the soil humidity to approximately $60 \%$ of the total pore volume, obtained by the densities of particles and soil and determined by the test tube method according to the methodology described by Embrapa (1997). Cultivation practices were performed manually according to plant requirements. 


\section{Evaluation of the study and calculation of indices}

After 150 days of cultivation, morphological variables were measured, including plant height $(\mathrm{PH})$, number of leaves (NL), stem diameter (SD), length of plagiotropic branch (LPB), and root length $(\mathrm{RL})$. $\mathrm{PH}$ and $\mathrm{LPB}$ were obtained using a graduated ruler, with the values expressed in $\mathrm{cm}$. SD was measured using a precision caliper at the cervical region and expressed in $\mathrm{mm}$ and the NL was counted. To measure RL, roots were removed from the soil, washed in water, and wiped on paper towels. A sample of approximately $5 \%$ of the fresh weight of roots was removed, with the aim of estimating the total length of roots using the interception line method, as described by Tennant (1975).

Plants were collected after evaluation, and stems, branches, leaves, and roots were separated. These sections were placed in separate paper bags and put into a laboratory oven, with forced air circulation, at a temperature of $65^{\circ} \mathrm{C}$, until their weight became constant, and weight of the dry matter was determined. The dry matter of leaves (DML), stems and branches (DMS), and roots (DMR) were determined separately. Material was weighed on an analytical balance and the results expressed in g per plant. Total dry matter (TDM) was the sum of DML, DMS, and DMR. From the relationship between DMR and DML+DMS, the ratio of roots:shoots (LRR) was calculated.

Plant dry matter was used to determinate the $\mathrm{P}$ content of roots, stems, and leaves, following the methodology described by Embrapa (1997), and total content of P (AP) was calculated. Using the dry matter and content of nutrients in the plants, nutritional indices of efficiency were calculated [absorption efficiency (AE) (Swiader et al., 1994); translocation efficiency (TE) (Li et al., 1991); and utilization efficiency (EU) (Siddiqi and Glass, 1981)]:

$\mathrm{AE}=$ (total content of nutrient in the plant) $/$ (dry matter of roots)

$T E=[($ nutrient content in the shoot $) /($ total nutrient content of the plant) $] \times 100$

$\mathrm{EU}=(\text { total dry matter })^{2} /$ (total nutrient content of the plant)
(Equation 1)

(Equation 2)

(Equation 3)

\section{Statistical analysis}

The data were subjected to individual analyses of variance, using the $F$ test, in order to identify the characteristics for which there was differentiation between means for the genotypes studied. Based on the individual analyses, using the fixed model:

$$
\mathrm{Y}_{\mathrm{ij}}=\mu+\mathrm{g}_{\mathrm{i}}+\varepsilon_{\mathrm{ij}}
$$

(Equation 4)

Estimates were calculated for genotypic coefficient of variation $\left(\mathrm{CV}_{\mathrm{g}}\right)$, quadratic component of genotypic variability $\left(\widehat{\Phi}_{g}\right)$, and coefficient of genotypic determination $\left(\mathrm{H}^{2}\right)$ for each trait.

Classification of genotypes regarding their tolerance to low availability of $P$ in the soil was undertaken using two criteria. Initially, the different characteristics of the plants were used 
to compare their growth using the Tukey test to identify genotypes that were able to grow under conditions of low availability of $\mathrm{P}$ (higher tolerance) and genotypes that were not able to develop satisfactorily (lower tolerance). Sequentially, a multivariate analysis, employing discriminant functions of Anderson, was performed to classify the genotypes whose tolerance had intermediate behavior in one of two known groups (tolerant and intolerant). In this procedure, a set of characteristics were selected, based on their relevance to diversity, to be used simultaneously in order to estimate the discriminant functions, which were used to calculate the scores and rankings, of the genotypes. All analyses used the 5\% significance level and were conducted using the statistical software Genes (Cruz, 2013).

\section{RESULTS}

\section{Genetic parameters}

The estimated values of the coefficient of genetic variation and the quadratic component of genotypic variability showed adequate expression of heterogeneity among genotypes in relation to the characteristics evaluated in this experiment: higher values were observed for variables in plants subjected to lower $\mathrm{P}$ supply in the soil (Table 2).

Table 2. Coefficient of genetic variation $\left(\mathrm{CV}_{\mathrm{g}}\right)$, quadratic genotypic variability $\left(\hat{\Phi}_{g}\right)$, and coefficient of genotypic determination $\left(\mathrm{H}^{2}\right)$ of 14 variables of conilon coffee genotypes grown with 0,50 , and $100 \%$ of the recommended fertilization with phosphorus $(P)$, at 150 days of cultivation.

\begin{tabular}{|c|c|c|c|c|c|c|c|c|c|}
\hline \multirow[t]{2}{*}{ Parameter } & \multicolumn{3}{|c|}{$\mathrm{PH}^{1}$} & \multicolumn{3}{|c|}{$\mathrm{SD}^{2}$} & \multicolumn{3}{|c|}{$\mathrm{PBL}^{3}$} \\
\hline & $0 \%$ & $50 \%$ & $100 \%$ & $0 \%$ & $50 \%$ & $100 \%$ & $0 \%$ & $50 \%$ & $100 \%$ \\
\hline $\mathrm{CV}_{\mathrm{g}}$ & 20.75 & 10.85 & 7.39 & 20.42 & 5.45 & 4.20 & 24.57 & 11.92 & 6.56 \\
\hline$\hat{\phi}_{g}{ }^{g}$ & 34.55 & 15.25 & 8.94 & 1.41 & 0.16 & 0.12 & 25.50 & 10.48 & 4.48 \\
\hline $\mathrm{H}^{2}$ & 95.44 & 91.39 & 94.13 & 96.69 & 84.33 & 83.98 & 98.33 & 96.00 & 83.73 \\
\hline Mean & 28.32 & 35.97 & 40.46 & 5.83 & 7.45 & 8.23 & 29.40 & 27.15 & 32.25 \\
\hline \multirow[t]{2}{*}{ Parameter } & \multicolumn{3}{|c|}{$\mathrm{RL}^{4}$} & \multicolumn{3}{|c|}{$\mathrm{NL}^{5}$} & \multicolumn{3}{|c|}{$\mathrm{DMR}^{6}$} \\
\hline & $0 \%$ & $50 \%$ & $100 \%$ & $0 \%$ & $50 \%$ & $100 \%$ & $0 \%$ & $50 \%$ & $100 \%$ \\
\hline $\mathrm{CV}_{\mathrm{g}}$ & 44.51 & 30.93 & 24.98 & 31.53 & 24.76 & 14.10 & 51.95 & 27.27 & 21.62 \\
\hline$\hat{\phi}_{g}{ }^{9}$ & 12.535 & 17.476 & 31.555 & 146.72 & 164.55 & 130.62 & 9.91 & 9.90 & 13.73 \\
\hline $\mathrm{H}^{2}$ & 99.74 & 91.20 & 99.57 & 98.71 & 99.06 & 98.65 & 99.40 & 98.09 & 97.55 \\
\hline Mean & 251.51 & 427.32 & 710.90 & 38.41 & 51.79 & 81.04 & 6.06 & 11.53 & 17.13 \\
\hline \multirow[t]{2}{*}{ Parameter } & \multicolumn{3}{|c|}{$\mathrm{DML}^{7}$} & \multicolumn{3}{|c|}{$\mathrm{DMS}^{8}$} & \multicolumn{3}{|c|}{$\mathrm{TDM}^{9}$} \\
\hline & $0 \%$ & $50 \%$ & $100 \%$ & $0 \%$ & $50 \%$ & $100 \%$ & $0 \%$ & $50 \%$ & $100 \%$ \\
\hline $\mathrm{CV}_{\mathrm{g}}$ & 11.51 & 13.78 & 7.97 & 52.29 & 23.72 & 14.91 & 23.83 & 16.69 & 8.71 \\
\hline$\hat{\phi}_{g}{ }^{9}$ & 11.51 & 18.95 & 9.97 & 3.78 & 2.13 & 2.19 & 64.05 & 67.71 & 33.74 \\
\hline $\mathrm{H}^{2}$ & 96.55 & 98.10 & 95.11 & 98.41 & 97.69 & 94.55 & 99.02 & 98.75 & 96.47 \\
\hline Mean & 23.80 & 31.58 & 39.61 & 3.71 & 6.16 & 9.93 & 33.58 & 49.28 & 66.68 \\
\hline \multirow[t]{2}{*}{ Parameter } & \multicolumn{3}{|c|}{$\mathrm{LRR}^{10}$} & \multicolumn{3}{|c|}{$\mathrm{AP}^{11}$} & \multicolumn{3}{|c|}{$A E^{12}$} \\
\hline & $0 \%$ & $50 \%$ & $100 \%$ & $0 \%$ & $50 \%$ & $100 \%$ & $0 \%$ & $50 \%$ & $100 \%$ \\
\hline $\mathrm{CV}_{\mathrm{g}}$ & 41.89 & 17.34 & 21.98 & 23.46 & 20.44 & 12.79 & 76.09 & 18.42 & 16.33 \\
\hline$\dot{\phi}_{g}{ }^{g}$ & 0.01 & 0.01 & 0.01 & 73.55 & 179.73 & 169.70 & 39.72 & 1.23 & 0.92 \\
\hline $\mathrm{H}^{2}$ & 98.48 & 94.44 & 96.41 & 98.74 & 99.37 & 98.63 & 99.99 & 99.89 & 99.90 \\
\hline Mean & 0.21 & 0.30 & 0.34 & 36.55 & 64.56 & 101.83 & 8.28 & 6.01 & 5.88 \\
\hline \multirow[t]{2}{*}{ Parameter } & & $\mathrm{TE}^{13}$ & & \multicolumn{3}{|c|}{$\mathrm{UE}^{14}$} & & & \\
\hline & $0 \%$ & $50 \%$ & $100 \%$ & $0 \%$ & $50 \%$ & $100 \%$ & & & \\
\hline $\mathrm{CV}_{\mathrm{g}}$ & 36.35 & 4.54 & 11.16 & 28.62 & 17.93 & 11.95 & & & \\
\hline$\hat{\phi}_{g}{ }^{g}$ & 38.05 & 13.27 & 83.34 & 76.52 & 42.86 & 29.15 & & & \\
\hline $\begin{array}{l}r_{g} \\
\mathrm{H}^{2}\end{array}$ & 99.97 & 99.94 & 99.95 & 99.99 & 99.87 & 99.87 & & & \\
\hline Mean & 84.40 & 80.12 & 81.79 & 30.56 & 36.48 & 45.17 & & & \\
\hline
\end{tabular}

${ }^{1}$ Plant height (cm); ${ }^{2}$ stem diameter $(\mathrm{mm}) ;{ }^{3}$ plagiotrophycal branch length $(\mathrm{cm}) ;{ }^{4}$ root length $(\mathrm{cm}) ;{ }^{5}$ number of leaves; ${ }^{6} \mathrm{dry}$ matter of roots $(\mathrm{g}) ;{ }^{7}$ dry matter of leaves $(\mathrm{g}) ;{ }^{8} \mathrm{dry}$ matter of stems $(\mathrm{g}) ;{ }^{9}$ total dry matter $(\mathrm{g}) ;{ }^{10}$ leaf root ratio; ${ }^{11}$ content of $\mathrm{P}$ in the aerial part (mg); ${ }^{12}$ absorption efficiency $(\mathrm{mg} / \mathrm{g}) ;{ }^{13}$ translocation efficiency $(\%) ;{ }^{14}$ utilization efficiency. 
Overall, for those variables where a high coefficient of genotypic determination was observed, indicating less influence of the environment on these variables, a superior trend in the treatments with low availability of $P$ in the soil was also observed. This result lead to the selection of the environment with the lowest $P$ availability in the soil (without addition of $\mathrm{P}_{2} \mathrm{O}_{5}$ ) in order to study the response of the genotypes in the following analyses.

\section{Response of genotypes to low availability of phosphorus}

The response of genotypes to cultivation in an environment with low $\mathrm{P}$ availability enabled the identification of genotypes with satisfactory and unsatisfactory growth. Mean values for the morphological variables of genotypes grown in an environment without the addition of $P$ are presented in Table 3. Genotype 24 grew relatively well compared with the other genotypes, obtaining higher mean values for PH, SD, RL, NL, DMR, DML, DMS, TDM, AP, and UE. In contrast, genotype 32 presented low accumulation of dry matter, resulting in low mean values for DMR, DML, TDM, LRR, AP, and UE. Thus, genotypes 24 and 32 were used as standards of tolerance and intolerance, respectively, for cultivation in soil with low P availability. Initially, the other genotypes were classified as having intermediate tolerance.

\section{Discrimination of tolerance}

The variables PH, SD, LPB, RL, NL, DMR, DML, DMS, TDM, LRR, AP, AE, TE, and UE were used to generate discriminant functions based on the results of the genotypes mentioned above, and were called $D_{t}(x)$ for tolerance and $D_{i}(x)$ for intolerance:

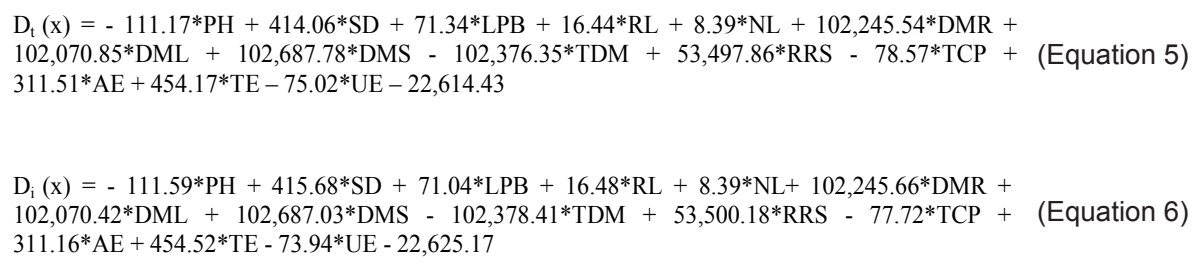

Discrimination based on the scores of the functions classified genotypes $67,83,77,76$, 22,23 , and 24 as tolerant to low availability of $P$ in the soil and genotypes $02,31,32,48,73$, and 153 as intolerant (Table 4). Notably, the genotypes that were used as the standards of tolerance and intolerance (24 and 32, respectively) maintained their rating correctly. This shows the statistical consistency of the generated functions and validates the inferences and proposed classification for the genotypes of undefined behavior.

It was not possible to establish a relationship between the duration of the ripening cycle and the qualitative discrimination for tolerance to low availability of $P$ in the soil. The results showed that tolerant genotypes, such as 23 and 67 (early ripening cycle), 22, 77, and 83 (intermediate ripening cycle), and 24 and 76 (late ripening cycle), behave similarly regardless of the characteristics of their ripening cycle (Table 4). 


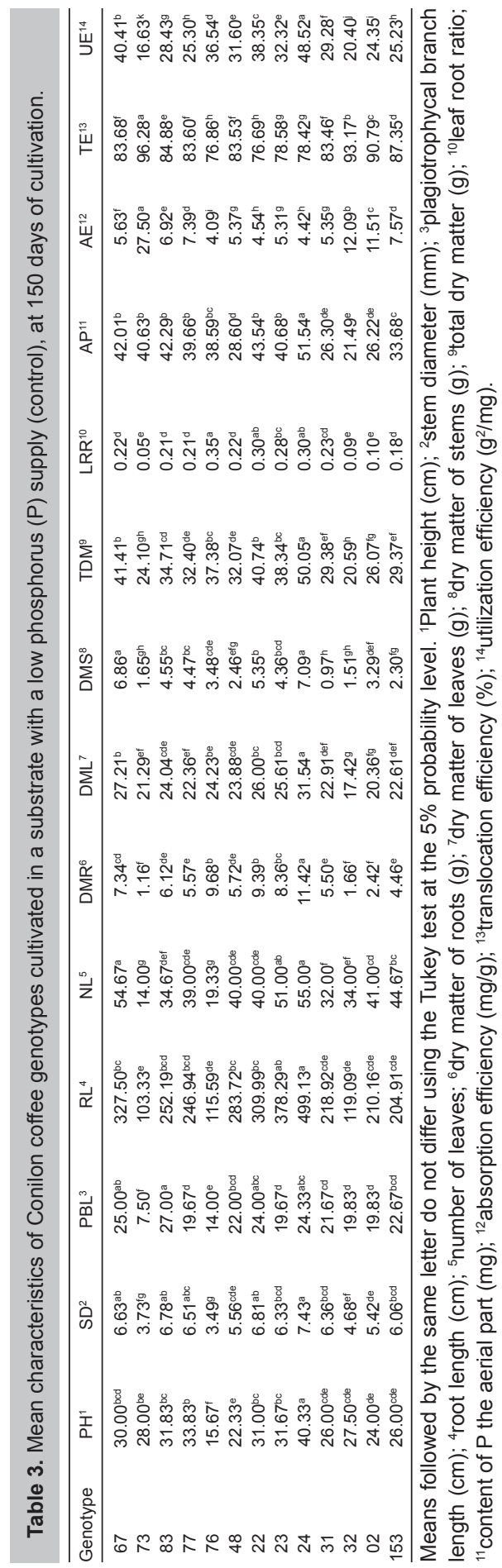


Table 4. Classification of the genotypes of Conilon coffee based on development under low availability of phosphorus in the soil, according to estimates of the discriminant functions $D_{t}(x)$ and $D_{i}(x)$ for tolerant and intolerant genotypes, respectively.

\begin{tabular}{lllll}
\hline Genotype & Ripening cycle & $\mathrm{D}_{\mathrm{t}}(\mathrm{x})$ & $\mathrm{D}_{\mathrm{i}}(\mathrm{x})$ & Classification \\
\hline 67 & Early & $22,484.61$ & $22,482.76$ & Tolerant \\
73 & Intermediate & $22,557.02$ & $22,558.88$ & Intolerant \\
83 & Intermediate & $22,776.69$ & $22,774.83$ & Tolerant \\
77 & Intermediate & $22,436.40$ & $22,434.54$ & Tolerant \\
76 & Late & $22,722.76$ & $22,720.90$ & Tolerant \\
48 & Early & $22,237.70$ & $22,239.56$ & Intolerant \\
22 & Intermediate & $22,396.59$ & Tolerant \\
23 & Early & $22,657.34$ & $22,394.73$ & Tolerant \\
24 & Late & $22,816.96$ & $22,85.48$ & Tolerant \\
31 & Intermediate & $22,741.04$ & $22,742.90$ & Intolerant \\
32 & Early & $22,534.09$ & $22,535.94$ & Intolerant \\
02 & Early & $22,948.32$ & $22,950.18$ & Intolerant \\
153 & Late & $22,713.41$ & $22,715.27$ & Intolerant \\
\hline
\end{tabular}

Discriminant functions estimated using the Anderson method.

\section{DISCUSSION}

\section{Differential tolerance to an environment with restricted phosphorus supply}

The explanation for the different behaviors of the genotypes of Conilon coffee regarding their tolerance to low $\mathrm{P}$ supply in the soil is related to the wide genetic variability found in this species (Table 2). The high variability of genotypes being bred in Brazil, which often leads to wide phenotypic variation within this species of coffee, has been reported in various studies (Fonseca et al., 2004; Ferrão et al., 2008; Rodrigues et al., 2012; Barbosa et al., 2014).

In environments with a low supply of nutrients, the main survival strategy for plants is to accumulate nutrients and transform them into dry matter, in particular in leaves to promote the development of photosynthetically active areas (Taiz and Zeiger, 2013). This evidence explains the fact that TDM and AP were higher for genotype 24 (tolerant) and lower for genotype 32 (intolerant), when compared to the remaining genotypes (Table 3). This fact was the second starting point for understanding the discrimination of tolerance among genotypes, and it also corroborates with the results of other studies involving the nutrition of these genotypes (Martins et al., 2013c; Colodetti et al., 2014).

Revisiting other nutritional experiments, it is evident that genotype 24 has a high accumulation of $P$ when cultivated in soils with low availability of $P$ and this trend is not maintained when the nutrient supply increases towards the actual recommended level. Contrarily, genotype 32 has reduced capacity to accumulate $\mathrm{P}$ when grown in environments with low availability of this nutrient; however, this genotype can increase the accumulation of $\mathrm{P}$ up to $700 \%$ when the nutrient supply increases, in contrast to only $310 \%$ achieved by genotype 24 (Martins et al., 2013b). This finding implies that the capacity to discriminate genotypes for tolerance may be strongly connected to the nutritional efficiency expressed by the genotypes, particularly the efficiency to utilize P from the soil. Recent studies have classified genotype 24 as nutritionally efficient, but unresponsive to increases in $\mathrm{P}$ fertilization, and genotype 32 as inefficient, but responsive to phosphorous fertilization. This may partially explain the fact that tolerance is related to the capacity of the genotypes to express efficiency in environments with nutritional limitations, and indicates that genotypes classified as intolerant may be, in most cases, very responsive to increases in $\mathrm{P}$ fertilization to recommended levels (Martins et 
al., 2013a). This direct relationship was evidenced for the genotypes in this study (Table 4), except for genotypes 73 and 153, which have been previously classified as inefficient and unresponsive (Martins et al., 2013a), and both were identified here as intolerant.

\section{Relationship between tolerance and ripening cycle}

Genotypes of Conilon coffee showed no relationship between tolerance to low P availability in the soil and duration of the ripening cycle (Table 4). In contrast, some studies have reported that genotypes of Conilon coffee with early maturation (genotypes 02,31 , and 153) have higher growth rates and accumulation of nitrogen $(\mathrm{N}), \mathrm{P}$, potassium, calcium, magnesium, sulfur, and dry matter (Morais et al., 2012; Prezotti and Bragança, 2013; Partelli et al., 2013, 2014). However, other studies showed that, in recommended growing conditions, early maturation may be linked to the efficiencies of absorption and utilization of $P$, and when modifying the supply of $P$, the behavior of genotypes varies (Martins et al., 2013a, Martins et al., 2013c), with no apparent evidence of change in the levels of tolerance.

Moreover, there is evidence that there is no direct relationship between the ripening cycle and tolerance to low levels of $\mathrm{N}$ in the soil (Colodetti et al., 2014). The variation in results regarding this relationship may be related to the condition of low availability of nutrients in the soil being used to discriminate genotype tolerance, while other studies used modified environments to supply of all nutrients (Partelli et al., 2013, 2014). The restricted supply of nutrients may promote the expression of genes for adaptation and, therefore, result in the expression of traits related to tolerance, as seen in Table 2.

For example, genotype 02 is intolerant to low levels of both $\mathrm{P}$ and $\mathrm{N}$ (Colodetti et al., 2014) and presents an early ripening cycle, while genotype 76 is tolerant of low levels of $P$ and $N$ (Colodetti et al., 2014) and has a late cycle. This fact demonstrates that, for young plants, the results diverge from the hypothesis presented in some other studies (Partelli et al., 2013, 2014). In addition, Rodrigues et al. (2012) studied several genotypes of Conilon coffee from each group of ripening cycle and monitored biometric characteristics over four years, concluding that no tendency of superiority occurred among the genotype groups of early, intermediate, and late ripening cycle.

In general, the tolerance of genotypes of Conilon coffee to low levels of $\mathrm{P}$ appears to be linked to i) the efficiency of accumulating total dry matter and $P$ in their tissues, ii) the partial increase in the utilization efficiency of $\mathrm{P}$, and by iii) the adaptability to stressful environments supported by the genetic variability of this species.

In conclusion, genotypes $22,23,24,67,76,77$, and 83 are tolerant to low availability of $P$ in the soil during early development. There is no clear relationship between the duration of the ripening cycle and the tolerance of the genotypes to low $\mathrm{P}$ availability in the soil. The genotypes express high genotypic variability in environments with low $\mathrm{P}$ availability in the soil.

\section{Conflicts of interest}

The authors declare no conflict of interest.

\section{ACKNOWLEDGMENTS}

The authors are grateful to Centro de Ciências Agrárias da Universidade Federal do Espírito Santo (CCA-UFES) for supporting this research, providing access to the necessary facilities, and laboratories. 


\section{REFERENCES}

Amaral JFT, Martins LD, Laviola BG, Christo LF, et al. (2012). A differential response of physic nut genotypes regarding phosphorus absorption and utilization is evidenced by a comprehensive nutrition efficiency analysis. J. Agric. Sci. 4: 164-173.

Barbosa DH, Rodrigues WP, Vieira HD, Partelli FL, et al. (2014). Adaptability and stability of Conilon coffee in areas of high altitude. Genet. Mol. Res. 13: 7879-7888.

Bragança SM, Martinez HEP, Leite HG, Santos LP, et al. (2010). Acumulação de matéria seca pelo cafeeiro conilon. Rev. Ceres 57: 48-52.

Colodetti TV, Rodrigues WN, Martins LD and Tomaz MA (2014). Differential tolerance between genotypes of conilon coffee (Coffea canephora) to low availability of nitrogen in the soil. Aust. J. Crop Sci. 8: 1648-1657.

Cruz CD (2013). GENES: a software package for analysis in experimental statistics and quantitative genetics. Acta Sci. Agron. 35: 271-276.

DaMatta FM, Ronchi CP, Maestri M and Barros RS (2007). Ecophysiology of coffee growth and production. Braz. J. Plant Physiol. 19: 485-510.

Embrapa - Empresa Brasileira de Pesquisa Agropecuária (1997). Manual de métodos de análises e classificação de solo. 2nd edn. MAPA, Rio de Janeiro.

Fageria NK (1998). Otimização da eficiência nutricional na produção das culturas. Rev. Bras. Eng. Agríc. Ambient. 2: 6-16.

Ferrão RG, Cruz CD, Ferreira A, Cecon PR, et al. (2008). Parâmetros genéticos em café Conilon. Pesq. Agropec. Bras. 43: 61-69.

Fonseca AFA, Ferrão MAG, Ferrão RG, Verdin Filho AC, et al. (2004). 'Conilon Vitória-Incaper 8142': improved Coffea canephora var. kouillou clone cultivar for the state of Espírito Santo. Crop Breed. Appl. Biotechnol. 4: 503-505.

Fox RH (1978). Selection for phosphorus efficiency in corn. Comm. Soil Sci. Plant Anal. 9: 13-37.

Lana RMQ, Zanão LA, Correia NM and Lana AMQ (2006). Variabilidade entre genótipos de feijoeiro na eficiência no uso do fósforo. Cienc. Rural 36: 778-784.

Lani JA, Prezotti LC and Bragança SM (2007). Cafeeiro. In: Manual de recomendação de calagem e adubação para o Estado do Espírito Santo-5a aproximação (Prezotti LC, Gomes JA, Dadalto GG and Oliveira JA, eds). SEEA/INCAPER/ CEDAGRO, Vitória, 111-118.

Lashermes P, Couturon E, Moreau N, Paillard M, et al. (1996). Inheritance and genetic mapping of self-incompatibility in Coffea canephora Pierre. Theor. Appl. Genet. 93: 458-462.

Li B, Mckeand SE and Allen HL (1991). Genetic variation in nitrogen use efficiency of loblolly pine seedlings. Forest Sci. 37: 613-626.

Machado CTT, Machado AT and Furlani AC (2004). Variação intrapopulacional em milho para características relacionadas com a eficiência de absorção e utilização de fósforo. Rev. Bras. de Milho e Sorgo 3: 77-91.

Martins LD, Tomaz MA, Amaral JFT, Braganca SM, et al. (2013a). Nutritional efficiency in clones of conilon coffee for phosphorus. J. Agric. Sci. 5: 130-140.

Martins LD, Tomaz MA, Amaral JFT, Braganca SM, et al. (2013b). Efficiency and response of conilon coffee clones to phosphorus fertilization. Rev. Ceres 60: 406-411.

Martins LD, Tomaz MA, Amaral JFT, Christo LF, et al. (2013c). Alterações morfológicas em clones de cafeeiro conilon submetidos a níveis de fósforo. Sci. Plena 9: 1-11.

Morais LE, Cavatte PC, Detmann KC, Sanglard LM, et al. (2012). Source strength increases with the increasing precociousness of fruit maturation in field-grown clones of conilon coffee (Coffea canephora) trees. Trees 26: 1397-1402.

Novais RF, Smyth TJ and Nunes FN (2007). Fósforo. In: Fertilidade do solo (Alvarez VH, Barros NF, Fontes RLF, Cantarutti RB and Neves JCL, eds). Sociedade Brasileira de Ciência de Solo, Viçosa, 471-550.

Partelli FL, Marré WB, Falqueto AR, Vieira HD, et al. (2013). Seasonal Vegetative growth in genotypes of Coffea canephora, as related to climatic factors. J. Agric. Sci. 5: 108-116.

Partelli FL, Espindula MC, Marré WB and Vieira HD (2014). Dry matter and macronutrient accumulation in fruits of Conilon coffee with different ripening cycles. Rev. Bras. Cienc. Solo 38: 214-222.

Prezotti LC and Bragança SM (2013). Acúmulo de massa seca, N, P e K em diferentes materiais genéticos de café conilon. Coffee Sci. 8: 284-294.

Rodrigues WN, Tomaz MA, Ferrão RG, Ferrão MAG, et al. (2012). Estimativa de parâmetros genéticos de grupos de clones de café Conilon. Coffee Sci. 7: 177-186.

Rotili EA, Fidelis RR, Santos MM, Barros HB, et al. (2010). Eficiência do uso e resposta à aplicação de fósforo de cultivares de arroz em solos de terras altas. Bragantia 69: 705-709.

Siddiqi MY and Glass ADM (1981). Utilization index: a modified approach to the estimation and comparison of nutrient utilization efficiency in plants. J. Plant Nutr. 4: 289-302. 
Silva L, Marchiori PER, Maciel CP, Machado EC, et al. (2010). Fotossíntese, relações hídricas e crescimento de cafeeiros jovens em relação à disponibilidade de fósforo. Pesq. Agropec. Bras. 45: 965-972.

Swiader JM, Chyan Y and Freiji FG (1994). Genotypic differences in nitrate uptake and utilization efficiency in pumpkin hybrids. J. Plant Nutr. 17: 1687-1699.

Taiz L and Zeiger E (2013). Fisiologia vegetal. 5th edn. Artmed, Porto Alegre.

Tennant D (1975). A test of a modified lineline intersects method of estimating root length. J. Ecol. 63: 995-1001.

Tomaz MA, Martinez HEP, Rodrigues WN, Ferrari RB, et al. (2011). Eficiência de absorção e utilização de boro, zinco, cobre e manganês em mudas enxertadas de cafeeiro. Rev. Ceres 58: 108-114. 